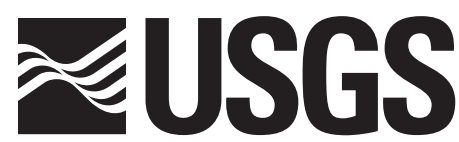

science for a changing world

Prepared in cooperation with the U.S. Bureau of Reclamation

\title{
Determination of Total Mercury in Whole-Body Fish and Fish Muscle Plugs Collected from the South Fork of the Humboldt River, Nevada, September 2005
}

Open-File Report 2007-1059 



\section{Determination of Total Mercury in Whole-Body Fish and Fish Muscle Plugs Collected from the South Fork of the Humboldt River, Nevada, September 2005}

By Thomas W. May and William G. Brumbaugh

Prepared in cooperation with the U.S. Bureau of Reclamation

Open-File Report 2007-1059

U.S. Department of the Interior

U.S. Geological Survey 


\section{U.S. Department of the Interior DIRK KEMPTHORNE, Secretary}

\section{U.S. Geological Survey \\ Mark D. Myers, Director}

U.S. Geological Survey, Reston, Virginia 2007

For product and ordering information:

World Wide Web: http://www.usgs.gov/pubprod

Telephone: 1-888-ASK-USGS

For more information on the USGS - the Federal source for science about the Earth,

its natural and living resources, natural hazards, and the environment:

World Wide Web: http://www.usgs.gov

Telephone: 1-888-ASK-USGS

\footnotetext{
Suggested citation:

May, T.W., and Brumbaugh, W.G., 2007, Determination of total mercury in whole-body fish and fish muscle plugs collected from the South Fork of the Humboldt River, Nevada, September 2005: U.S. Geological Survey Open-File Report 2007-1059, 4 p.

Any use of trade, product, or firm names is for descriptive purposes only and does not imply endorsement by the U.S. Government.
}

Although this report is in the public domain, permission must be secured from the individual copyright owners to reproduce any copyrighted material contained within this report. 


\section{Contents}

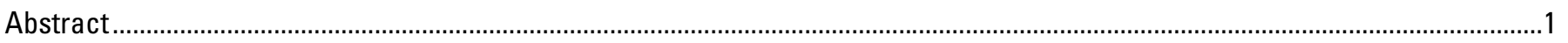

Introduction

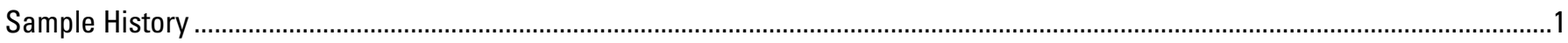

Methods

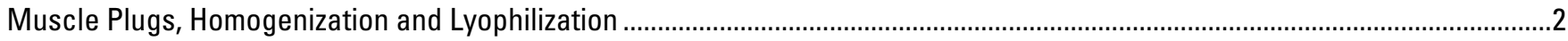

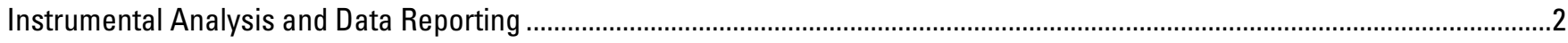

Results and Discussion

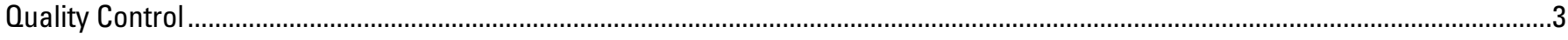

References Cited

\section{Tables}

1. Total mercury concentrations in whole-body fish and fish muscle plugs from the South Fork of the Humboldt River,

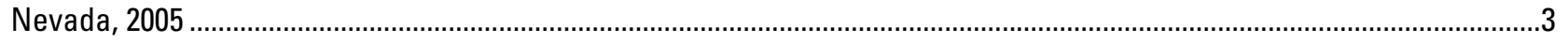

2. Total mercury concentrations in dry tissue powders submitted with whole-body fish samples, 2005 ..............................3

\section{Conversion Factors}

\begin{tabular}{lcl}
\hline \multicolumn{1}{c}{ Multiply } & By & To obtain \\
\hline \multicolumn{2}{c}{ Mass } & \\
\hline gram $(\mathrm{g})$ & 0.03527 & ounce $(\mathrm{oz})$ \\
milligram $(\mathrm{mg})$ & .000035 & ounce $(\mathrm{oz})$ \\
\hline \multicolumn{3}{c}{ Length } \\
\hline millimeter $(\mathrm{mm})$ & 0.0394 & inches (in) \\
\hline
\end{tabular}

Temperature in degrees Celsius $\left({ }^{\circ} \mathrm{C}\right)$ may be converted to degrees Fahrenheit $\left({ }^{\circ} \mathrm{F}\right)$ as follows: ${ }^{\circ} \mathrm{F}=\left(1.8 \mathrm{x}^{\circ} \mathrm{C}\right)+32$

Concentrations of chemical constituents in solid materials are given in microgram per gram $(\mu \mathrm{g} / \mathrm{g})$. 


\title{
Determination of Total Mercury in Whole-Body Fish and Fish Muscle Plugs Collected from the South Fork of the Humboldt River, Nevada, September 2005
}

\author{
By Thomas W. May and William G. Brumbaugh
}

\begin{abstract}
This report presents the results of a study by the U.S. Geological Survey, done in cooperation with the U.S. Bureau of Reclamation, to determine mercury concentrations in whole-body fish and fish muscle plugs from the South Fork of the Humboldt River near Elko in the Te-Moak Indian Reservation. A single muscle plug was collected from beneath the dorsal fin area in each of the three whole-body fish samples. After homogenization and lyophilization of the muscle plugs and whole-body fish samples, mercury concentrations were determined with a direct mercury analyzer utilizing the process of thermal combustion-gold amalgamation atomic absorption spectroscopy. Mercury concentrations in whole-body fish ranged from 0.048 to 0.061 microgram per gram wet weight, and 0.061 to 0.082 microgram per gram wet weight in muscle plugs. All sample mercury concentrations were well below the U.S. Environmental Protection Agency's fish consumption advisory of 0.30 microgram per gram wet weight.
\end{abstract}

\section{Introduction}

The U.S. Geological Survey (USGS) conducted a study in cooperation with the U.S. Bureau of Reclamation (USBR) to determine the concentrations of mercury in whole-body fish and fish muscle plugs from the South Fork of the Humboldt River near Elko in the Te-Moak Indian Reservation. The whole-body fish mercury data represents the total mercury body burden available to wildlife fish consumers; whereas the fish muscle plug data are used to evaluate human consumption risks. The USBR will use the data from this study to make future management decisions concerning fish harvests from the South Fork of the Humboldt River. The data will be provided to state and local agencies responsible for evaluating the potential risk to the public from fish consumption. Fish health advisories will be issued if necessary.

\section{Sample History}

A shipment of five samples was received by the Inorganic Chemistry section of the USGS on October 21, 2005. Three whole-body fish and two tissue powder samples were collected by USBR on September 30, 2005. Upon receipt, the samples were assigned USGS batch number 1212 and USGS identification numbers 35336-35340. 


\section{Methods}

\section{Muscle Plugs, Homogenization and Lyophilization}

After partial thawing, a single muscle plug was collected with a 5-mm (millimeter) stainless steel biopsy punch from beneath the dorsal fin area in each of the three whole-body fish samples 3533735339. Using clean forceps, the skin from each plug was removed with a stainless steel scalpel and the remaining tissue was transferred to a pre-cleaned polyethylene cryovial. Once created, the muscle plug samples were given new USGS identification numbers 35341-35343. Each whole-body fish sample was minced with a titanium meat cleaver. These minced samples, muscle plug samples, and the two tissue powder samples were then lyophilized with a Virtis Genesis ${ }^{\circledR}$ 35EL freeze dryer and percent moisture was determined as part of the lyophilization procedure. Once dried, each minced whole-body fish sample was further homogenized by hand-kneading in a sealed plastic bag. All dried samples were stored in glass vials in a desiccator.

\section{Instrumental Analysis and Data Reporting}

Mercury was determined with a direct mercury analyzer. With this method, a dried sample of approximately 31 to $69 \mathrm{mg}$ (milligrams) was combusted in a stream of oxygen. All mercury in the sample was volatilized and trapped by amalgamation on a gold substrate and was thermally desorbed and quantitated by atomic absorption spectrophotometry (U.S. Environmental Protection Agency, 2003). The entire sequence was conducted with a Milestone Direct Mercury Analyzer (DMA-80) equipped with an automated sample carousel. Triplicate determinations were conducted for the wholebody fish and tissue powder samples and the mean of the three analyses was reported. Because of the limited biomass, only one determination could be performed for each muscle plug sample. The concentrations of mercury measured in whole-body fish samples and fish muscle plugs were converted to wet weight for reporting. Concentrations of samples received as powders were reported "as received." Based on historical measurements, residual moisture of homogenized, lyophilized, and desiccator-stored fish fillet tissue typically is 3 to 5 percent, but no attempt was made to apply a correction for residual moisture of individual dry samples because the mercury analyzer is calibrated with dried certified reference tissues having similar ranges of moisture content. The uncertainty of reported wet-weight concentrations, potentially because of moisture differences among the individual dried unknown samples and the certified reference samples used for the calibration, is expected to be considerably less than the overall method uncertainty (plus or minus 5 to 10 percent for mean concentrations at least three fold above the method quantitation limit). Furthermore, the uncertainty associated with moisture variation among dry sample determinations should be no greater than the uncertainty associated with moisture variation among fresh or frozen fish fillet sample analyses.

\section{Results and Discussion}

Percent moisture and mean concentrations of total mercury measured in whole-body fish and a muscle plug from each of those fish are presented in table 1. Percent moisture in whole-body fish ranged from 71.8 to 73.8 percent and averaged 73.0 percent, whereas moisture content of muscle tissue ranged from 75.1 to 79.4 percent. Mercury concentrations in whole-body fish ranged from 0.048 to $0.061 \mu \mathrm{g} / \mathrm{g}$ (microgram per gram) wet weight and averaged $0.054 \mu \mathrm{g} / \mathrm{g}$ wet weight. The concentration of mercury in each fish muscle plug was about 30 percent greater than the corresponding whole-body 
residue. These ranged from 0.061 to $0.082 \mu \mathrm{g} / \mathrm{g}$ wet weight and averaged $0.070 \mu \mathrm{g} / \mathrm{g}$ wet weight. All sample concentrations were well below the U.S. Environmental Protection Agency's fish consumption advisory of $0.30 \mu \mathrm{g} / \mathrm{g}$ wet weight (U.S. Environmental Protection Agency, 2001).

Percent moistures and concentrations $(\mu \mathrm{g} / \mathrm{g}$ as received) of total mercury in submitted tissue powder samples are presented in table 2. Percent moistures were 5.4 and 5.2 percent. As mentioned earlier, mercury concentrations were not corrected for this residual moisture because the DMA-80 is calibrated using dried reference tissue powders with comparable residual moisture values.

Table 1. Total mercury concentrations in whole-body fish and fish muscle plugs from the South Fork Humboldt River, Nevada, 2005.

[USGS, U.S. Geological Survey; ID, identification; g, gram; mm, millimeter; n, number; $\mu \mathrm{g} / \mathrm{g}$, microgram per gram wet weight]

\begin{tabular}{|c|c|c|c|c|c|c|c|c|}
\hline $\begin{array}{l}\text { USGS ID } \\
\text { number }\end{array}$ & $\begin{array}{l}\text { Field ID } \\
\text { number }\end{array}$ & Sample type & $\begin{array}{c}\text { Fish weight } \\
\text { (g) }\end{array}$ & $\begin{array}{c}\text { Fish fork } \\
\text { length } \\
(\mathrm{mm})\end{array}$ & $\begin{array}{c}\text { Fish total } \\
\text { length } \\
(\mathrm{mm})\end{array}$ & $\begin{array}{l}\text { Percent } \\
\text { moisture }\end{array}$ & $\mathrm{n}$ & $\begin{array}{c}\text { Mean total } \\
\text { mercury } \\
(\mu \mathrm{g} / \mathrm{g})\end{array}$ \\
\hline 35337 & LCCSIF002 & whole-body & 70.4 & 175 & 184 & 73.5 & 3 & 0.048 \\
\hline 35338 & LCCSIF003 & whole-body & 148. & 232 & 239 & 73.8 & 3 & 0.061 \\
\hline \multirow[t]{5}{*}{35339} & LCCSIF004 & whole-body & 475. & 338 & 351 & 71.8 & 3 & 0.053 \\
\hline & $\begin{array}{l}\text { USGS ID } \\
\text { number }\end{array}$ & $\begin{array}{l}\text { Field ID } \\
\text { number }\end{array}$ & Sample type & $\begin{array}{l}\text { Percent } \\
\text { moisture }\end{array}$ & $\mathrm{n}$ & $\begin{array}{c}\text { Total mercury } \\
(\mu \mathrm{g} / \mathrm{g})\end{array}$ & & \\
\hline & 35341 & P130-LCCSIF002 & muscle plug & 77.3 & 1 & 0.061 & & \\
\hline & 35342 & P131-LCCSIF003 & muscle plug & 79.4 & 1 & 0.082 & & \\
\hline & 35343 & P132-LCCSIF004 & muscle plug & 75.1 & 1 & 0.068 & & \\
\hline
\end{tabular}

Table 2. Total mercury concentrations in dry tissue powders submitted with wholebody fish samples, 2005.

[USGS, U.S. Geological Survey; ID, identification; n, number; $\mu \mathrm{g} / \mathrm{g}$, microgram per gram as received]

\begin{tabular}{ccccc}
\hline $\begin{array}{c}\text { USGS ID } \\
\text { number }\end{array}$ & $\begin{array}{c}\text { Field/lab ID } \\
\text { number }\end{array}$ & $\begin{array}{c}\text { Percent } \\
\text { moisture }\end{array}$ & $\mathbf{n}$ & $\begin{array}{c}\text { Mean total } \\
\text { mercury } \\
(\boldsymbol{\mu g} / \mathbf{g})\end{array}$ \\
\hline 35336 & LCCSIF001 & 5.4 & 3 & 2.85 \\
35340 & LCCSIF005 & 5.2 & 3 & 2.88 \\
\hline
\end{tabular}

\section{Quality Control}

The samples were handled in one group, or block, through the instrumental analysis. Quality control included blanks, replicates, pre-combustion spikes, and tissue reference materials. During the instrumental run, additional quality control included independent calibration verification checks. 
For the group or block of samples, two independent calibration verification samples [National Research Council Canada (NRCC) DOLT-2 and International Atomic Energy Agency (IAEA) 407] were analyzed at the beginning and end of the instrumental run to confirm the calibration status of the DMA-80 system; each measured calibration sample was within plus or minus 10 percent of the certified concentration. Five reference tissues were analyzed for mercury: NRCC DORM-2 (n=1), National Institute of Standards and Technology (NIST) RM50 [n=1 (one sample)], IAEA 407 (n=2), NRCC DOLT-2 (n=2), NIST $2976(n=3)$; recoveries of mercury were within certified or recommended ranges. Method precision can be estimated from the percent relative standard deviation (RSD) from triplicate analysis of a sample. Percent RSDs from triplicate analyses of whole-body fish samples $(n=3)$ and unspecified dry tissue powders $(n=2)$ were less than or equal to 13 percent. Percent recovery of methylmercury hydroxide from pre-combustion tissue spikes $(n=2)$ were 110 and 112 percent. Although all spike recoveries were above 100 percent, the mean recovery was well within quality-control protocol target limits (80 to 120 percent). Moreover, spike recoveries are not necessarily the best indicator of accuracy for the DMA-80 method because the instrumental response for liquids is sometimes slightly different than for solids. The blank equivalent concentration for total mercury $(0.00003 \mu \mathrm{g} / \mathrm{g}$ dry weight) was less than the method detection limit. The instrument detection limit was $0.007 \mu \mathrm{g} / \mathrm{g}$ dry weight mercury. The method detection limit was $0.011 \mu \mathrm{g} / \mathrm{g}$ dry weight mercury, and the method quantitation limit was $0.038 \mu \mathrm{g} / \mathrm{g}$ dry weight. Overall, the quality control was within acceptable limits as specified by the USGS.

\section{References Cited}

U.S. Environmental Protection Agency, 2001, Water quality criterion for protection of human healthMethylmercury: Washington, D.C., U.S. Environmental Protection Agency, Office of Water, EPA823-R-01-001, 269 p.

U.S. Environmental Protection Agency, 2003, Draft update IVA of SW-846, 7000 series, Method 7473, Mercury in solids and solutions by thermal decomposition, amalgamation, and atomic absorption spectrophotometry: accessed July, 2005 at URL http://www.epa.gov/epaoswer/hazwaste/test/ up4a.htm\#7_series. 
For more information concerning the research described in this report, contact:

U.S. Geological Survey

Columbia Environmental Research Center

4200 New Haven Road

Columbia, M0 65201

(573) 875-5399

http://www.cerc.usgs.gov 


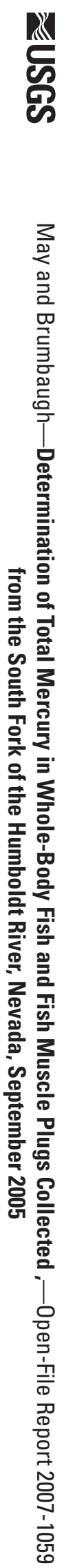

(4) Printed on recycled paper 